Cite this: Dalton Trans., 2013, 42, 15927

Received 4th June 2013,

Accepted 23rd August 2013

DOI: $10.1039 / c 3 d t 51485 d$

www.rsc.org/dalton

\section{Oxo-carboxylato-molybdenum(vi) complexes possessing dithiolene ligands related to the active site of type II DMSOR family molybdoenzymest}

\author{
Hideki Sugimoto, ${ }^{\text {*a }}$ Masanori Sato, ${ }^{a}$ Logan J. Giles, ${ }^{b}$ Kaori Asano, ${ }^{c}$ Takeyuki Suzuki, ${ }^{c}$
} Martin L. Kirk ${ }^{\star b}$ and Shinobu Itoh ${ }^{* a}$

\begin{abstract}
Spectroscopic and kinetic studies indicate that oxo-carboxylatomolybdenum( $(\mathrm{vI})$ bis-dithiolene complexes, $\left(\mathrm{Mo}^{\mathrm{VI}} \mathrm{O}(p-\mathrm{X}-\mathrm{OBz}) \mathrm{L}_{2}\right)$, have been generated at low temperature as active site structural models for the type II class of pyranopterin molybdenum DMSOR family enzymes. A DFT analysis of low energy charge transfer bands shows that these complexes possess a Mo- $S_{\text {dithiolene }}$ $\pi$-bonding interaction between the $\operatorname{Mo}\left(d_{x y}\right)$ redox active molecular orbital and a cis $S\left(p_{z}\right)$ donor orbital located on one of the dithiolene ligands.
\end{abstract}

The vast majority of pyranopterin molybdenum enzymes catalyse oxygen atom transfer reactions between the substrate and solvent water coupled with proton and electron transfer. ${ }^{1}$ The dimethyl sulfoxide reductase (DMSOR) family of pyranopterin molybdenum enzymes is unique in that they possess two pyranopterin ene-1,2-dithiolate ligands bound to the Mo ion. ${ }^{1}$ The active site Mo centre is the locus of the oxygen atom transfer reactivity and can adopt desoxomolybdenum(Iv) and monooxomolybdenum(vi) structures during the catalytic cycle. ${ }^{1,2}$ Phylogenic analysis and protein sequence alignments of the metalbinding regions have been used to further subdivide DMSOR family enzymes into three types: I, II and III (Fig. 1). ${ }^{3}$ Type I enzymes possess a Cys or SeCys residue that coordinates to the molybdenum centre, ${ }^{4}$ while type II and type III enzymes have a metal center coordinated by an Asp and a Ser residue, respectively. ${ }^{2,5}$

\footnotetext{
${ }^{a}$ Department of Material and Life Science, Graduate School of Engineering, Osaka University, 2-1 Yamadaoka, Suita, Osaka 565-0871, Japan.

E-mail:sugimoto@mls.eng.osaka-u.ac.jp, shinobu@mls.eng.osaka-u.ac.jp

${ }^{b}$ Department of Chemistry and Chemical Biology, The University of New Mexico, MSC03 2060, 1 University of New Mexico, Albuquerque, New Mexico 87131-0001, USA.E-mail: mkirk@unm.edu

${ }^{c}$ Comprehensive Analysis Centre, The Institute of Scientific and Industrial Research (ISIR), Osaka University, 8-1 Mihogaoka, Ibaraki, Osaka 567-0057, Japan

$\dagger$ Electronic supplementary information (ESI) available: Experimental details for the preparation, low temperature measurements and DFT calculations (Tables S1-S2, Fig. S1-S8). See DOI: 10.1039/c3dt51485d
}

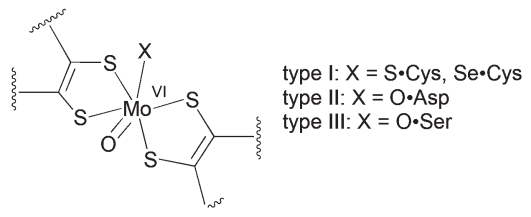

Fig. 1 The active site structures of oxidized type I, II and III enzymes.

Extensive studies of bis(ene-1,2-dithiolate)molybdenum complexes as active site structural models have been carried out by Holm and co-workers. ${ }^{6-8}$ Specifically, these researchers have synthesised and structurally characterised a number of desoxomolybdenum(Iv) complexes employing 1,2-dimethylethylene-1,2-dithiolate $\left(\mathrm{S}_{2} \mathrm{C}_{2} \mathrm{Me}_{2}\right)$ together with $\mathrm{RS}^{-}, \mathrm{RSe}^{-}$, $\mathrm{RCOO}^{-}$, and $\mathrm{RO}^{-}$ligands $(\mathrm{X})^{6}$ that are structurally related to the molybdenum(Iv) active site structures of DMSOR type I, II and III enzymes. ${ }^{7}$ However, the corresponding monooxomolybdenum(vi) complexes, $\left[\mathrm{Mo}^{\mathrm{VI}} \mathrm{O}(\mathrm{L})\left(\mathrm{S}_{2} \mathrm{C}_{2} \mathrm{Me}_{2}\right)_{2}\right]^{-}$, have proved too unstable for full characterisation due to an auto-redox reaction between the $\mathrm{Mo}^{\mathrm{VI}}$ ion and the monodentate ligand $\mathrm{L}$ that results in the formation of the five-coordinate $\left[\mathrm{Mo}^{\mathrm{V}} \mathrm{O}\left(\mathrm{S}_{2} \mathrm{C}_{2} \mathrm{Me}_{2}\right)_{2}\right]^{-}$complex. ${ }^{7,8}$ The only crystallographically characterised example of a $\left[\mathrm{Mo}^{\mathrm{VI}} \mathrm{O}(\mathrm{L})(\text { ene-1,2-dithiolate })_{2}\right]^{-}$ complex is $\left[\mathrm{Mo}^{\mathrm{VI}} \mathrm{O}\left(\mathrm{OSi}^{\mathrm{i}} \mathrm{Pr}_{3}\right)\left(\mathrm{S}_{2} \mathrm{C}_{2}(\mathrm{COOMe})_{2}\right)_{2}\right]^{-}\left(\mathbf{M o}^{\mathrm{VI}} \mathbf{O}\left(\mathbf{O S i}^{\mathrm{i}} \mathbf{P r}_{3}\right)^{-}\right.$ $\left(\mathrm{L}^{\text {COOMe }}\right)_{2}, \quad \mathrm{~S}_{2} \mathrm{C}_{2}(\mathrm{COOMe})_{2}=$ 1,2-dicarbomethoxyethylene-1,2dithiolate), where the six-coordinate structure appears to be stabilised by the presence of electron-withdrawing methoxycarbonyl (-COOMe) groups on the dithiolene. ${ }^{9} \mathbf{M o}^{\mathbf{V I}} \mathbf{O}\left(\mathbf{O S i}^{\mathbf{i}} \mathbf{P r}_{3}\right)$ $\left(\mathrm{L}^{\text {COOMe }}\right)_{2}$ best represents a synthetic analogue of the DMSOR type III enzyme active sites. Recently, we prepared and characterised oxosulfido- and oxoselenido-molybdenum(vi) complexes at low temperature as active site models for the xanthine oxidase family of pyranopterin molybdenum enzymes. ${ }^{10}$ Herein, we report the successful application of low temperature techniques to generate and characterise new bis(ene-1,2-dithiolate)oxocarboxylatomolybdenum(vi) complexes, which can be regarded as structural models for oxidised 
members of type II DMSOR family enzymes. Additionally, we provide an initial electronic structure description of these bis(ene-1,2-dithiolate)oxocarboxylatemolybdenum(vi) complexes using DFT calculations. The designation and abbreviation of the complex structures are given in Chart S1.†

Initial attempts to prepare the oxocarboxylatomolybdenum(vi) complex $\mathbf{M o}^{\mathbf{V}} \mathbf{O}(\boldsymbol{p}$-H-OBz $) \mathbf{L}_{2} \quad(\mathbf{L}=$ cyclohexene-1,2-dithiolate$\left(\mathrm{S}_{2} \mathrm{C}_{2} \mathrm{C}_{4} \mathrm{H}_{8}\right)$ ) utilised an oxo-transfer reaction from the tertiary amine oxide $\left(\mathrm{Me}_{3} \mathrm{NO}\right)$ to the benzoatomolybdenum(Iv) complex, $\mathbf{M o}^{\mathbf{I V}}(\boldsymbol{p}-\mathbf{H}-\mathbf{O B z}) \mathbf{L}_{2}$, at room temperature under an inert $\mathrm{Ar}$ atmosphere. However, the grey coloured oxomolybdenum(v) complex $\left[\mathbf{M o}^{\mathrm{V}} \mathrm{O}\left(\mathrm{S}_{2} \mathrm{C}_{2} \mathrm{C}_{4} \mathrm{H}_{8}\right)_{2}\right]^{-}\left(\mathbf{M o}^{\mathrm{V}} \mathbf{O L}_{2}\right)$ was obtained instead of the anticipated oxocarboxylatomolybdenum(vi) complex $\mathbf{M o}^{\mathbf{V I}} \mathbf{O}(\boldsymbol{p}-\mathbf{H}-\mathbf{O B z}) \mathbf{L}_{2}$. The formation of $\mathbf{M o}^{\mathbf{V}} \mathbf{O}($ ene-1,2dithiolate $)_{2}$ has also been reported in the reaction of $\left[\mathrm{Mo}^{\mathrm{IV}}(\mathrm{X})\right.$ $\left.\left(\mathrm{S}_{2} \mathrm{C}_{2} \mathrm{Me}_{2}\right)_{2}\right]^{-}$with tertiary amine oxides or sulfoxides. ${ }^{8} \mathrm{We}$ attempted to observe the formation of $\left(\mathbf{M o}^{\mathbf{V I}} \mathbf{O}(\boldsymbol{p}-\mathbf{H}-\mathbf{O B z}) \mathbf{L}_{2}\right.$ at low temperatures, but the reaction between $\mathbf{M o}^{\mathbf{I V}}(\boldsymbol{p}-\mathbf{H}-\mathbf{O B z}) \mathbf{L}_{2}$ and tertiary amine oxides does not proceed to a significant extent below $-40{ }^{\circ} \mathrm{C}$. Next, the reaction of the five-coordinate oxomolybdenum(vi) complex, $\mathbf{M o}^{\mathbf{V I}} \mathbf{O L}_{2}$ (synthesis in ESI $\dagger$ ), ${ }^{11}$ with the benzoate anion, $\mathrm{Et}_{4} \mathrm{~N}(p-\mathrm{H}-\mathrm{OBz})$, was examined in $\mathrm{C}_{2} \mathrm{H}_{5} \mathrm{CN}$ under an Ar atmosphere. At room temperature, this reaction also yielded the oxomolybdenum(v) complex $\left(\mathbf{M o}^{\mathrm{V}} \mathbf{O L}_{2}\right)$ (Fig. S1 $\dagger$ ), but at low temperature $\left(-60^{\circ} \mathrm{C}\right)$ the reaction yielded a deep-green EPR silent product. Fig. 2 shows the observed spectral changes upon addition of $p-\mathrm{H}-\mathrm{OBz}^{-}$to $\mathbf{M o}^{\mathrm{VI}} \mathrm{OL}_{2}$ in $\mathrm{C}_{2} \mathrm{H}_{5} \mathrm{CN}$ at $-60{ }^{\circ} \mathrm{C}$. Here, the absorption band at $395 \mathbf{n m}$ due to $\mathbf{M o}^{\mathbf{V I}} \mathbf{O L}_{2}$ decreases with the concomitant appearance of new absorption bands at $807 \mathrm{~nm}$ (band 1) and $597 \mathrm{~nm}$ (band 2). Tight isosbestic points are observed at 336, 367 and $445 \mathrm{~nm}$. Titration plots clearly indicate that the stoichiometry of $\mathrm{Mo}{ }^{\mathrm{VI}} \mathrm{OL}$ to $p-\mathrm{H}_{-}-\mathrm{OBz}^{-}$is $1: 1$ (Fig. 2, inset). The final spectrum is very similar to that of $\left[\mathrm{Mo}^{\mathrm{VI}} \mathrm{O}\left(\mathrm{OSi}^{\mathrm{i}} \mathrm{Pr}_{3}\right)^{-}\right.$ $\left.\left(\mathrm{S}_{2} \mathrm{C}_{2}(\mathrm{COOMe})_{2}\right)_{2}\right]^{-9}$, consistent with the formation of a sixcoordinate oxocarboxylatomolybdenum(vi) complex, $\left[\mathrm{Mo}^{\mathrm{VI}} \mathrm{O}-\right.$

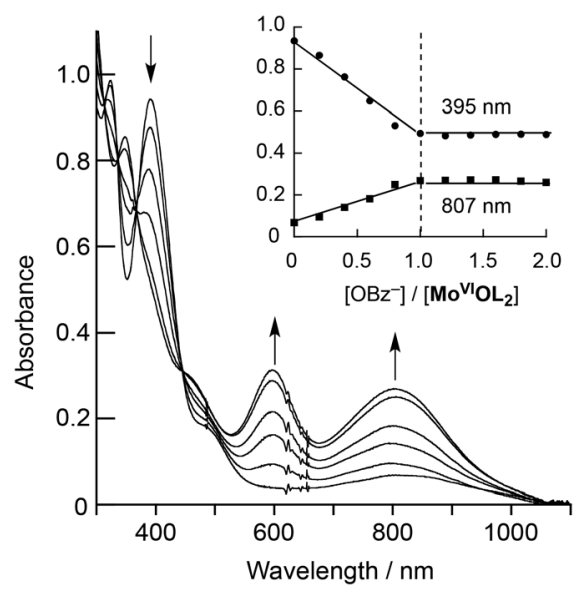

Fig. 2 Spectral changes observed upon addition of $1 / 5,2 / 5,3 / 5,4 / 5$, and 5/5 equiv. of $\mathrm{Et}_{4} \mathrm{~N}(p-\mathrm{H}-\mathrm{OBz})$ to $\mathbf{M o}^{\mathrm{VI}} \mathrm{OL}_{2}(0.2 \mathrm{mM})$ in $\mathrm{C}_{2} \mathrm{H}_{5} \mathrm{CN}$ at $-60{ }^{\circ} \mathrm{C}$; (inset) plots of the absorbance at 395 ( $)$ and 807 (⿴) $\mathrm{nm}$ against the molar ratio of $\left[p-\mathrm{H}-\mathrm{OBz}{ }^{-}\right] /\left[\mathrm{Mo}^{\mathrm{VI}} \mathrm{OL}_{2}\right]$.
$\left.(p-\mathrm{H}-\mathrm{OBz})\left(\mathrm{S}_{2} \mathrm{C}_{2} \mathrm{C}_{4} \mathrm{H}_{8}\right)_{2}\right]^{-}, \quad\left(\mathbf{M o}^{\mathrm{VI}} \mathbf{O}(\boldsymbol{p}-\mathrm{H}-\mathrm{OBz}) \mathbf{L}_{2}\right) . \quad \mathbf{M o}^{\mathbf{V I}} \mathbf{O}(p-\mathrm{OMe}-$ $\mathbf{O B z}) \mathbf{L}_{2}$ and $\mathbf{M o}^{\mathbf{V I}} \mathbf{O}(\boldsymbol{p}$-Cl-OBz $) \mathbf{L}_{2}$ possess similar spectral features to $\mathbf{M o}^{\mathbf{V I}} \mathbf{O}(\boldsymbol{p}-\mathbf{H}-\mathbf{O B z}) \mathbf{L}_{2}$ and were generated in a similar manner using $\mathrm{Et}_{4} \mathrm{~N}(p$-OMe-OBz $)$ and $\mathrm{Et}_{4} \mathrm{~N}(p-\mathrm{Cl}-\mathrm{OBz})$, respectively (Fig. S2 $\dagger$ ). The $\lambda_{\max }$ for band 1 shifts to lower energy as the substituent $\mathrm{X}$ changes from electron withdrawing to electron donating $(\mathrm{X}=\mathrm{Cl}, 793 \mathrm{~nm} ; \mathrm{X}=\mathrm{H}, 807 \mathrm{~nm}$; $\mathrm{X}=$ OMe, $814 \mathrm{~nm}$ ). This strongly supports the direct coordination of the benzoate ligand to the molybdenum(vi) centre. When warmed to room temperature, the UV-vis and EPR spectra converted to those of $\mathbf{M o}^{\mathbf{V}} \mathbf{O L}_{2}$.

Cyclic voltammograms of $0.1 \mathrm{M}^{n} \mathrm{Bu}_{4} \mathrm{NPF}_{6}-\mathrm{C}_{2} \mathrm{H}_{5} \mathrm{CN}$ solutions containing $\mathbf{M o}^{\mathbf{V I}} \mathbf{O L}_{2}$ and $\mathrm{Et}_{4} \mathrm{~N}(p-\mathrm{X}-\mathrm{OBz})(\mathrm{X}=\mathrm{Cl}, \mathrm{H}, \mathrm{OMe})$ in a $1: 1$ ratio were measured at $-60{ }^{\circ} \mathrm{C}$ and yielded one irreversible reduction wave below $-1 \mathrm{~V} v s$. SCE. The reduction peak potential is observed to shift in a negative direction $(\mathrm{Cl}$, $E_{\mathrm{pc}}=-1.08 \mathrm{~V} ; \mathrm{H}, E_{\mathrm{pc}}=-1.16 ; \mathrm{OMe}, E_{\mathrm{pc}}=-1.18 \mathrm{~V} v s$. SCE) as the $\mathrm{p} K_{\mathrm{a}}$ value of the $p$-substituted benzoic acid increases (3.99 for $\mathrm{X}=\mathrm{Cl}, 4.20$ for $\mathrm{X}=\mathrm{H}$ and 4.50 for $\mathrm{X}=\mathrm{OMe}$ ). This result provides support for the coordination of the $p-\mathrm{X}-\mathrm{OBz}$ anion to the Mo center of $\mathbf{M o}^{\mathbf{V I}} \mathbf{O L}_{2}$ since the electron-donating substituent increases the basicity of the benzoate anion and enhances its ability to coordinate to $\mathrm{Mo}^{\mathrm{VI}}$. The CSI-mass spectrum of a $\mathrm{C}_{2} \mathrm{H}_{5} \mathrm{CN}$ solution containing $\mathbf{M o}^{\mathbf{V I}} \mathbf{O L}_{2}$ and 1 equiv. of $\mathrm{Et}_{4} \mathrm{~N}$ $(p$-OMe-OBz) showed a peak cluster attributable to [Mo$(p$-OMe-OBz $\left.)\left(\mathrm{S}_{2} \mathrm{C}_{2} \mathrm{C}_{4} \mathrm{H}_{8}\right)_{2}\right]^{-}$at $m / z=537$ at $-60{ }^{\circ} \mathrm{C}$ (Fig. S3 $\dagger$ ). Since the UV-vis spectrum of the $\mathrm{C}_{2} \mathrm{H}_{5} \mathrm{CN}$ solution of the product shown in Fig. 2 is different from that of $\left[\mathrm{Mo}^{\mathrm{IV}}(p-\mathrm{OMe}-\right.$ $\left.\mathrm{OBz})\left(\mathrm{S}_{2} \mathrm{C}_{2} \mathrm{C}_{4} \mathrm{H}_{8}\right)_{2}\right]^{-}$synthesised separately from $\left[\mathrm{Mo}^{\mathrm{IV}}\right.$ $\left.\left(\mathrm{S}_{2} \mathrm{C}_{2} \mathrm{C}_{4} \mathrm{H}_{8}\right)_{2}\right]$ and $p$-OMe-OBz ${ }^{-}$, this peak cluster is likely to be a fragment of $\mathbf{M o}^{\mathbf{V I}} \mathbf{O}(\boldsymbol{p}$-OMe-OBz $) \mathbf{L}_{2}$. Therefore, we conclude that $\mathbf{M o}^{\mathbf{V I}} \mathbf{O}(\boldsymbol{p}-\mathbf{H}-\mathbf{O B z}) \mathbf{L}_{2}$ and its para substituted derivatives are formed at low temperature by coordination of the benzoates to the molybdenum(vi) centre of $\mathbf{M o}^{\mathbf{V I}} \mathbf{O L}_{2}$.

In order to obtain information about the mechanism of $\mathbf{M o}^{\mathbf{V I}} \mathbf{O}(\boldsymbol{p}-\mathbf{X}-\mathbf{O B z}) \mathbf{L}_{2}$ formation, a low temperature kinetic study was performed. The spectral changes observed upon addition of the benzoate ligand to $\mathbf{M o}^{\mathbf{V I}} \mathbf{O L}_{2}$ were observed to be biphasic. The data show a rapid disappearance of the $\mathbf{M o}^{\mathbf{V I}} \mathbf{O L}_{2}$ $395 \mathrm{~nm}$ band and the appearance of a new absorption band at $360 \mathrm{~nm}$ due to intermediate A that converts to $\mathbf{M o}^{\mathbf{V I}} \mathbf{O}(\boldsymbol{p}-\mathbf{X}-\mathbf{O B z})-$ $\mathbf{L}_{2}$ with characteristic absorption bands at 597 and $807 \mathrm{~nm}$ (Fig. S4a and $4 \mathrm{~b} \dagger$ ). Although the time course of the first step was too fast to be followed accurately, the conversion of intermediate A to $\mathbf{M o}^{\mathbf{V I}} \mathbf{O}(\boldsymbol{p}-\mathbf{X}-\mathbf{O B z}) \mathbf{L}_{2}$ obeys first-order kinetics. It should be noted that the observed first-order rate constant, $k_{\text {obs }}$, was independent of the concentration of $\mathrm{Et}_{4} \mathrm{~N}(p-\mathrm{H}-\mathrm{OBz})$ (Fig. S5 $\dagger$ ). The formation of $\mathbf{M o}^{\mathbf{V I}} \mathbf{O}(\boldsymbol{p}-\mathbf{C l}-\mathbf{O B z}) \mathbf{L}_{2}$ and $\mathbf{M o}^{\mathbf{V I}} \mathbf{O}$ $(\boldsymbol{p}$-OMe-OBz $) \mathbf{L}_{2}$ displayed kinetic behavior similar to $\mathbf{M o}^{\mathbf{V I}} \mathbf{O}$ $(\boldsymbol{p}$-H-OBz $) \mathbf{L}_{2}$ with $k_{\mathrm{obs}}$ increasing as the electron-withdrawing character of $\mathrm{X}$ increases: $65.8 \times 10^{-3} \mathrm{~s}^{-1}$ for $\mathrm{X}=\mathrm{Cl}, 7.2 \times 10^{-3} \mathrm{~s}^{-1}$ for $\mathrm{X}=\mathrm{H}$ and $1.4 \times 10^{-3} \mathrm{~s}^{-1}$ for $\mathrm{X}=$ OMe. These observations suggest that the first step is the association (coordination) of the benzoate anion with the Mo center of $\mathbf{M o}^{\mathbf{V I}} \mathbf{O L}_{2}$, giving intermediate $\mathrm{A}$, and the second step is the intramolecular rearrangement of intermediate A to the product (Scheme 1). 


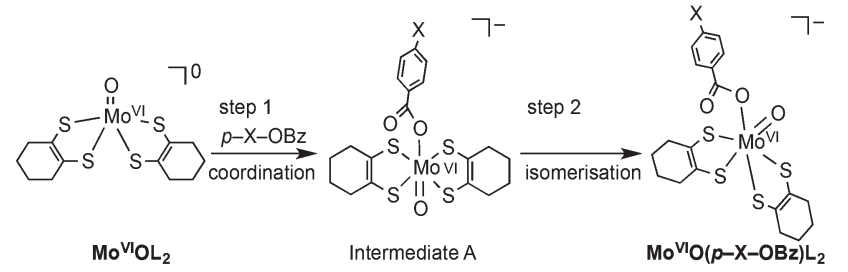

Scheme 1 Proposed mechanism for formation of $\mathbf{M o}^{\mathrm{VI}} \mathbf{O}(p-\mathrm{X}-\mathrm{OBz}) \mathrm{L}$.
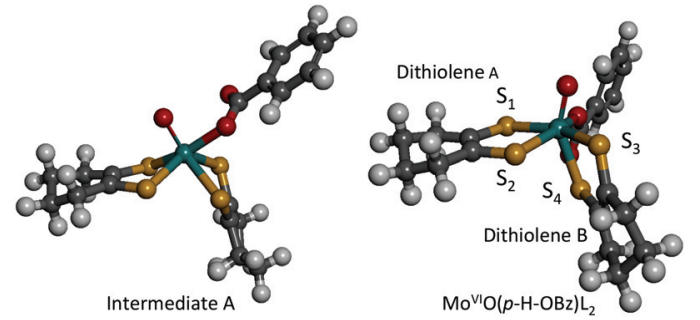

Fig. 3 Computed structures of intermediate $A$ (left) and $\mathbf{M o}^{\mathrm{V}} \mathrm{O}(\boldsymbol{p}-\mathrm{H}-\mathrm{OBz}) \mathrm{L}_{2}$ (right).

DFT calculations support an idealised $C_{2 \mathrm{v}}$ structure with respect to the two $\mathrm{S}_{2} \mathrm{C}_{2} \mathrm{C}_{4} \mathrm{H}_{8}$ ligands for intermediate $\mathrm{A}$ that subsequently rearranges via a Ray-Dutt type twist ${ }^{12}$ to form a more stable product with a distorted octahedral geometry (Fig. 3).

The DFT optimised structure of $\mathbf{M o}^{\mathrm{VI}} \mathbf{O}(\boldsymbol{p}-\mathbf{H}-\mathbf{O B z}) \mathbf{L}_{2}$ possesses a distorted octahedral coordination environment that is similar to the related $\mathbf{M o}{ }^{\mathbf{V I}} \mathbf{O}\left(\mathbf{O S i}^{\mathbf{i}} \mathbf{P r}_{3}\right)\left(\mathbf{L}^{\mathbf{C O O M e}}\right)_{2}$ (vide supra; Fig. 3), which has been previously characterised by X-ray crystallography. ${ }^{9}$ The computations indicate a slightly larger S1-S2-S3-S4 dithiolene dihedral angle for $\mathbf{M o}^{\mathrm{VI}} \mathbf{O}(\boldsymbol{p}-\mathbf{H}-\mathrm{OBz}) \mathbf{L}_{2}$ of $126^{\circ}$ compared with a $108^{\circ}$ dihedral angle for structurally characterised $\mathbf{M o}^{\mathrm{VI}} \mathbf{O}\left(\mathbf{O S i}^{\mathrm{i}} \mathbf{P r}_{3}\right)\left(\mathbf{L}^{\mathrm{COOMe}}\right)_{2}$. As was observed for $\mathbf{M o}^{\mathrm{VI}} \mathrm{O}\left(\mathrm{OSi}^{\mathrm{i}} \mathbf{P r}_{3}\right)\left(\mathbf{L}^{\mathrm{COOMe}}\right)_{2}$, the Mo-S4 bond distance $(2.55 \AA)$ is elongated when compared to the three Mo-S bonds (mean $2.42 \AA$ ) as a result of a strong trans influence due to the $\mathrm{Mo} \equiv \mathrm{O}$ bond. Geometry optimisations indicate that $\mathrm{Mo}^{\mathrm{VI}} \mathrm{O}(\boldsymbol{p}$-Cl-OBz $)$ $\mathbf{L}_{2}$ and $\mathbf{M o}^{\mathrm{VI}} \mathbf{O}(\boldsymbol{p}$-OMe-OBz $) \mathbf{L}_{2}$ possess $\mathrm{S} 2-\mathrm{S} 1-\mathrm{S} 3-\mathrm{S} 4$ dihedral angles, and $\mathrm{Mo}-\mathrm{S}, \mathrm{Mo} \equiv \mathrm{O}_{\mathrm{oxo}}$ and $\mathrm{Mo}-\mathrm{O}_{\mathrm{OBz}}$ bond distances, which are nearly identical to those of $\mathbf{M o}^{\mathrm{VI}} \mathbf{O}(\boldsymbol{p}-\mathbf{H}-\mathbf{O B z}) \mathbf{L}_{2}$. The computed structures for the $\mathbf{M o}^{\mathrm{VI}} \mathbf{O}(\boldsymbol{p}$-X-OBz $) \mathbf{L}_{2}$ complexes display $\sim 172^{\circ} \mathrm{O}_{\text {oxo }}-\mathrm{Mo}-\mathrm{S} 3-\mathrm{C}$ dihedral angles, allowing for strong Mo $\mathrm{d}_{x y}-\mathrm{S}_{\text {dithiolene }} \pi$-bonding involving a single S3 donor on dithiolene B. This is supported by bonding calculations that show a LUMO wavefunction which possesses a strong Mo- $\mathrm{S}_{\text {dithiolene }} \pi^{*}$ bonding interaction between the $\operatorname{Mo}\left(\mathrm{d}_{x y}\right)$ orbital and the cis $\mathrm{S} 3\left(\mathrm{p}_{z}\right)$ donor orbital located on dithiolene (B) (Table 1). This Mo-S $\pi^{*}$ bonding description is similar to what we observed in the related complex $\mathbf{M o}{ }^{\mathrm{VI}} \mathbf{O}\left(\mathbf{O S i}^{\mathrm{i}} \mathbf{P r}_{3}\right)\left(\mathbf{L}^{\mathrm{COOMe}}\right)_{2},{ }^{9}$ and this derives from the $\sim 180^{\circ} \mathrm{O}_{\text {oxo }}-\mathrm{Mo}-\mathrm{S}-\mathrm{C}$ dihedral angle involving the cis $\mathrm{S}$ of dithiolene $\mathrm{B}$.

The electronic absorption spectra of the $\mathbf{M o}^{\mathrm{VI}} \mathrm{O}(p-\mathbf{X}-\mathbf{O B z}) \mathbf{L}_{2}$ complexes display well-resolved bands at $\sim 800 \mathrm{~nm}$ and $\sim 600 \mathrm{~nm}$ (band 1: 12500 $\mathrm{cm}^{-1}, \varepsilon \sim 1375 \mathrm{M}^{-1} \mathrm{~cm}^{-1}$; and
Table 1 Molecular orbital compositions for $\mathrm{Mo}^{\mathrm{V}} \mathrm{O} \mathrm{O}(\mathrm{p}-\mathrm{H}-\mathrm{OBz}) \mathrm{L}_{2}$

\begin{tabular}{lrrrll}
\hline & \multicolumn{5}{c}{ Fragment character (\%) } \\
\cline { 2 - 6 } Molecular orbital & \multicolumn{1}{c}{ Mo } & Oxo & OBz & $\mathrm{S}_{2} \mathrm{C}_{4} \mathrm{H}_{8} \mathrm{~A}^{a}$ & $\mathrm{~S}_{2} \mathrm{C}_{4} \mathrm{H}_{8} \mathrm{~B}^{a}$ \\
\hline LUMO + 2 & 5 & 0 & 91 & $1(1)$ & $1(1)$ \\
LUMO + 1 & 59 & 22 & 5 & $8(4)$ & $6(5)$ \\
LUMO & 41 & 1 & 11 & $10(9)$ & $38(29)$ \\
HOMO & 5 & 5 & 1 & $63(37)$ & $26(18)$ \\
HOMO - 1 & 18 & 4 & 4 & $24(12)$ & $50(26)$
\end{tabular}

${ }^{a}$ Values in parentheses are the S contribution of the dithiolene.

band 2: $16700 \mathrm{~cm}^{-1}, \varepsilon \sim 1600 \mathrm{M}^{-1} \mathrm{~cm}^{-1}$, respectively). Using a combination of time-dependent DFT computations and our previous band assignments for $\mathbf{M o}^{\mathrm{VI}} \mathbf{O}\left(\mathrm{OSi}^{\mathbf{i P r} 3}\right)\left({ }^{\mathrm{LCOOMe}}\right)_{2},{ }^{9}$ we assigned band 1 as dominantly deriving from a HOMO $\rightarrow$ LUMO one-electron promotion with appreciable dithiolene $\mathrm{A} \rightarrow\left(\right.$ Mo d $_{x y}+$ dithiolene B) charge transfer character. The dominant contributor to band 2 is a HOMO $-1 \rightarrow$ LUMO (Mo-S3 $3_{\text {dithiolene }} \pi \rightarrow \mathrm{Mo} \mathrm{S} 3_{\text {dithiolene }} \pi^{*}$ ) one-electron promotion with dithiolene $\mathrm{A} \rightarrow \operatorname{Mo}\left(\mathrm{d}_{x y}\right)$ charge transfer character. The computations also suggest a variable HOMO $\rightarrow$ LUMO +2 contribution with benzoate acceptor character that leads to intensity differences in band 2 .

\section{Conclusions}

New bis(ene-1,2-dithiolato)oxocarboxylatomolybdenum(vi) complexes have been synthesized as active site analogues of type II DMSOR family enzymes. Low temperature kinetic and spectroscopic analyses, in conjunction with DFT calculations, have been used to understand their formation and electronic structure. Provided $\mathrm{DMSOR}_{\mathrm{ox}}$ possesses a hexacoordinate geometry; these results suggest that the ancillary $\mathrm{O}_{\text {asp }}$ ligand likely functions to fine tune the redox potential of the Mo ion. Interestingly, a hexacoordinate geometry also allows for a specific pyranopterin dithiolene to couple the active site into long-range superexchange pathways for electron transfer regeneration of the catalytically relevant $\mathrm{Mo}(\mathrm{Iv})$ site.

This work was partly supported by grants (no. 23350027, 24108725 and 2410915 to H.S. and no. 22105007 to S.I.). M.L.K. acknowledges the National Institutes of Health (GM 057378) for financial support. The authors also thank Dr Kei Ohkubo and Prof. Shunichi Fukuzumi of Osaka University for their help in collecting the EPR spectrum.

\section{Notes and references}

1 R. Hille, Chem. Rev., 1996, 96, 2757; S. J. N. Burgmayer, Prog. Inorg. Chem., 2004, 52, 491; M. J. Romao, Dalton Trans., 2009, 4053; R. Hille, Dalton Trans., 2013, 42, 3029.

2 H. Schindelin, C. Kisker, J. Hilton, K. V. Rajagopalan and D. C. Rees, Science, 1996, 272, 1615; H.-K. Li, C. Temple, 
K. V. Rajagopalan and H. Schindelin, J. Am. Chem. Soc., 2000, 122, 7673.

3 C. A. McDevitt, P. Hugenholtz, G. R. Hanson and A. G. McEwan, Mol. Microbiol., 2002, 44, 1575; A. G. McEwan, J. P. Ridge and C. A. McDevitt, Geomicrobiol. J., 2002, 19, 3.

4 J. C. Boyington, V. N. Gladyshev, S. V. Khangulov, T. C. Stadtman and P. D. Sun, Science, 1997, 275, 1305; J. M. Dias, M. E. Than, A. Humm, R. Huber, G. P. Bourenkov, H. D. Bartunik, S. Bursakov, J. Calvete, J. Calderia, C. Carneiro, J. J. G. Moura, I. Moura and M. J. Romao, Structure, 1999, 7, 65; M. Jormakka, S. Tornroth, B. Byrne and S. Iwata, Science, 2002, 295, 1863.

5 M. G. Bertero, R. A. Rothery, M. Palak, C. Hou, D. Lim, F. Blasco, J. H. Weiner and N. C. J. Strynadka, Nat. Struct. Biol., 2003, 10, 681; M. Jormakka, D. Richardson, B. Byrne and S. Iwata, Structures, 2004, 12, 95.

6 J. H. Enemark, J. J. A. Cooney, J.-J. Wang and R. H. Holm, Chem. Rev., 2004, 104, 1175; J. McMaster, J. M. Tunney and
C. D. Garner, Prog. Inorg. Chem., 2004, 52, 539; H. Sugimoto and H. Tsukube, Chem. Soc. Rev., 2008, 37, 2609; F. J. Hine, A. J. Taylor and C. D. Garner, Coord. Chem. Rev., 2010, 254, 1570; C. Schulzke, Eur. J. Inorg. Chem., 2011, 1189.

7 R. H. Holm, E. I. Solomon, A. Majumdar and A. Tenderholt, Coord. Chem. Rev., 2011, 255, 993.

8 B. S. Lim and R. H. Holm, J. Am. Chem. Soc., 2001, 123, 1920.

9 H. Sugimoto, S. Tatemoto, K. Suyama, H. Miyake, R. P. Mtei, S. Itoh and M. L. Kirk, Inorg. Chem., 2010, 49, 5368.

10 H. Sugimoto, S. Tatemoto, K. Toyota, M. Kubo, T. Ogura and S. Itoh, Chem. Commun., 2013, 49, 4358.

11 H. Sugimoto, M. Harihara, M. Shiro, K. Sugimoto, K. Tanaka, H. Miyake and H. Tsukube, Inorg. Chem., 2005, 44, 6386.

12 P. Ray and N. K. Dutt, J. Indian Chem. Soc., 1943, 20, 81. 